\title{
FRATURA DO COMPLEXO ZIGOMÁTICO-ORBITÁRIO: RELATO DE CASO
}

Ingrid Araujo OLIVEIRA; Nelson Luis Barbosa REBELLATO; Delson João da COSTA; Paulo Roberto MÜLLER; José Mário FRAIZ

Os traumas na região do zigomático não são necessariamente de grande intensidade, porém muitas vezes se apresentam sob a forma de disjunções, isto é, separação do zigomático dos ossos a ele unidos pelas suturas, que são os pontos frágeis não só do zigomático como também dos outros ossos da face. As fraturas orbitais são as que mais tem chances de se tornar complexas, devido à anatomia da região. O processo orbital do zigomático forma parte do assoalho da órbita, separando a cavidade orbital do seio maxilar (BARROS, 2000). Paciente J.T., do sexo masculino, 59 anos, leucoderma, foi encaminhado ao Serviço de Cirurgia e Traumatologia Buco-Maxilo-Faciais do Hospital XV, relatando queda de nível, apresentando edema e equimose periorbital, hemorragia subconjuntival esquerda e escoriações faciais. Este informou episódios de vômitos e desmaios, minutos após o ocorrido. Ao exame extra-oral verificou-se afundamento da região malar esquerda, ausência de qualquer alteração visual e boa abertura bucal. Aos exames de imagens, observou-se fratura do osso zigomático, rebordo infra-orbitário e em região fronto-zigomática do lado esquerdo. Para redução das fraturas, foram realizados acessos extra-oral e intra-bucal, sendo utilizado 03 miniplacas do sistema $2.0 \mathrm{~mm}$ e 12 parafusos de titânio para a fixação interna rígida. Após seis meses, o paciente encontra-se em proservação, tendo sido alcançado o restabelecimento funcional. 